\title{
Self-Care Skills of Children with Moderate Intellectual Disability
}

\author{
Heni Gerda Pesau1,2), Endang Widyorini'1), Sri Sumijati1) \\ 1)Faculty of Psychology, Universitas Soegijapranata Catholic, Semarang \\ 2)Faculty of Psychology, Universitas Atma Jaya, Makassar
}

\section{ABSTRACT}

Background: Intellectual disability is one of the developmental disorders that showing a delay in self-care skills that need to decrease the physical dependence of children to adults. Children with moderate intellectual disability could show differences in developmental and level of self-care skills that affected of few factors. The aim of the study is to explore the self-care skills of children with moderate intellectual disability on feeding, dressing, toileting, and self-hygiene, and factors that affect these skills.

Subjects and Method: This was a qualitative study with case study approach. A total of five subjects with moderate intellectual disability aged 7-12 years was selected for this study. The data were collected from eleven parents and teachers by interview. All data were analyzed by content analysis.

Results: All five subjects have different levels of each of the self-care skills and get help from teachers or parents in some of these activities. The amount of help is influenced by internal fac- tors such as physical and motor problems as indicated by observations of subject 2. External factors that are found are parental roles, self-care practicing methods, and differences in parent attitudes. Behavioral problems factor such as aggressive, self-harm, and social withdrawal was not found. Self-care programs and the coordination of parents and school as external factors were only found in subject 2 and 4 .

Conclusion: All five subjects showed varying abilities of the self-care skills and internal and external factors that affect these skills.

Keywords: moderate intellectual disability, selfcare skills, factors

\section{Correspondence:}

Heni Gerda Pesau. Faculty of Psychology, Universitas Atma Jaya, Makassar. Jl. Tanjung Alang No.23 Makassar, South Sulawesi, Indonesia. Email: henigerdao@gmail.com. Mobile: +6285341916728

Cite this as:

Pesau HG, Widyorini E, Sumijati S (2020). Self-Care Skills of Children with Moderate Intellectual Disability. J Health Promote Behav. 5(1): 43-49. https://doi.org/10.26911/thejhpb.2020.05.01.06

cc) (†) (-) Journal of Health Promotion and Behavior is licensed under a Creative Commons Journal of Health Promotion and Behavior is licensed under a Creat
Attribution-Non Commercial-Share Alike 4.0 International License.

BACKGROUND

One aspect of the abilities needed by children is independence that starts with the development of self-care skills (TATS eUpdate, 2010). The ability of self-care is part of the adaptive function which includes skills in dressing, eating, toileting, and personal hygiene (Mash and Wolfe, 2005). The ability of self-care needs to be developed because these skills can decrease the physical dependence of children to adults (Dowling, 2000). The term self-care is commonly used in school-age children who are expected to be responsible for self-care independently. School age is also called middle childhood (Papalia et al., 2009).

One of the developmental tasks in middle childhood, namely in the age range 6-12 years, is the achievement of personal independence in the ability to develop themselves (Havighurst in Gallahue and Ozmun, 2006). However, there are some conditions causing children not be able to achieve this developmental task, one is experiencing developmen- 
tal disabilities. This study will focus on intellectual disability that affects self-care skills.

Children who are identified by intellectual disability showing intelligence and adaptive abilities or daily life skills that are under their age and one of the characteristics is a delay in the ability of self-care (APA, 2013). Previous study showed that $61.6 \%$ of participants with intellectual disability have low self-care ability (Ramawati et al., 2012). The problem most often faced by parents who have children with intellectual disability is the lack of personal hygiene, especially bathing and defecating (Samsuri, 2013) or difficulties when dealing with toileting skills (Harrison et al., 2015).

The condition of independence is one of the concerns of parents who have children with intellectual disability (Klein, 2006). Likewise, individual with intellectual disability who experience barriers in understanding and always depend on others will increase the risk of experiencing violence or crime (Reis et al., 2013). Difficulties of children in toileting also affect children's activities because it can cause children to be excluded from social, joint activities or recreation, and from public schools. Moreover, it might facilitate health problems in the form of cleanliness of organs, dysentery, digestive infections, and it will make children feel uncomfortable (Snell, 1983).

Intellectual disability itself consists of several levels of severity, namely mild, moderate, severe, and profound (APA, 2013), in this study we will focus on moderate severity. Intellectual disability is being characterized by delays in all conceptual areas that require ongoing assistance (APA, 2013). This study will focus on moderate level because moderate only can achieve the middle of elementary school, so program more focus to increase self-care skills. In contrast, mild severity can achieve more in academic than moderate level, while children with severe inte- llectual disability will always need help from others (World Health Organization, 2004). In addition to explore the self-care skills of children with moderate intellectual disability, it is also necessary to know what factors affect these skills. Known is that the self-care of children with intellectual disabilities is affected by age and motor skills (Ramawati, 2011), mother's parenting style that is too pampering, stimulation provided by mothers (Stevenson, 1985), overrated parental protection (Hurlock, 1978), and mother's involvement (Anand, 2012).

Our initial observation and interviews of two subjects with moderate intellectual disability, KI (10 years) and SL (12 years) supported that despite having the same level of severity, different self-care ability were shown. While KI received assistance in almost all activities, SL was able to do some activities without assistance and was being trained for hygiene during menstruation. Preliminary data also showed that these two subjects showed developments in self-care ability.

Therefore, in addition to explore the self-care skills of children with moderate intellectual disability, it is also necessary to know what factors affect these skills. By knowing the factors that influence the ability of self-care, parents, teachers, or caregivers who are directly involved in practicing selfcare skills can improve children's self-care skills by increasing supporting factors or reduce factors that can interrupt the skills.

\section{SUBJECTS AND METHOD}

\section{Study Design}

This was a qualitative study with case study approach.

\section{Population and Sample}

Population of this study was children aged 712 years who had been diagnosed with moderate intellectual disability (ID) by a 
psychologist. A total sample of 5 children was selected for this study.

\section{Study Instruments}

The data to be collected in this study are the history of the subject's development, self-care ability consisting of the ability of feeding, dressing, toileting, self-hygiene, and factors that affect the internal and external skills. This study used systematic observation using narrative recording with specimen description techniques and semi-structured interviews to parents and teachers.

\section{Data Analysis}

The analysis conducted was a qualitative analysis, also called content analysis (Smith, 2013), which consists of several stages (Moleong, 2002), namely (1) reading and studying all available data from various sources, namely interviews and observations, (2) reducing data by coding, (3) giving names or labels to each category, (4) synthesizing or looking for links between one category and another, and labeled again, and (5) compiling work hypotheses by formulating proportional statements and at the same time answering the study problem statement.

\section{RESULTS}

\section{Sample Characteristics}

The study was conducted in two schools for children with special needs in Makassar. Five subjects at the age 7 - 12 years who had been diagnosed with moderate intellectual disability

\section{Content analysis}

The five subjects showed varying abilities in each aspect of self-care skills. In the feeding skills, four subjects were able to do this independently, while subject II still needed help. Regarding dressing ability, subjects II and IV still needed physical assistance, namely pulling zippers and buttoning up clothes. Subject IV is able to do almost all dress activities by herself, but the subject's mother was still helping and dressing the subject. None of the five subjects were able to wear strappy shoes. In the aspect of personal hygiene, subject III and subject IV were able to carry out activities without assistance.

Subject V still needs to be reminded to cleanse the body, while subjects I and II, still get help to wash their hair, brush their teeth, and cut their nails. Subject IV has been able to do personal hygiene without assistance while at school, but the mother is still doing it for subject at home. The fourth ability, namely toileting, subject III and subject V have been able to do it themselves without assistance. Subjects I and II have been able to defecate in the toilet but have not been able to wipe, while subject IV is still defecating in his pants and helped to wash.

The different abilities of self-care shown by the five subjects are influenced by several factors. Internal factors in this study consist of physical and motor conditions, health conditions, and the presence or absence of behavioral problems. Subjects I, III, $\mathrm{IV}$, and $\mathrm{V}$ did not experience problems or obstacles with physical and motoric conditions, on the contrary due to physical disability, subject II was still assisted while eating, buttoning clothes, pulling zippers, pockets, and other activities that required coordination of both hands and motor skills. None of the five subjects showed health and behavioral problem, it can be assumed that conditions where these problems are not present might be favorable for acquiring selfcare skills.

All five subjects showed development in self-care skills, this was also influenced by external factors, such as the role of parents who are directly involved in the subject training every day and parents understanding of the subject's conditions to experience obstacles, so requiring a special way in training. The way to train self-care, as was in this study is by repetitive, gradual training and 
done patiently and slowly. Parents and teachers also provide examples and physical assistance when needed, and use real objects as a medium in simulations conducted at school.

The next factor is the collaboration of teachers and parents such as working together to help overcome the constraints of physical conditions experienced by subject II and the teacher's efforts to always remind parent of subject IV to let the subject do things by herself, reduce assistance, and efforts to overcome toileting problems. In addition, other factors that also support the holding of selfcare programs in schools to train or improve the ability of self-care provided both individually and classically are the use of approaches or methods that are adapted to the subject's conditions.

\begin{tabular}{|c|c|c|}
\hline & $\begin{array}{l}\text { Children with Moderate } \\
\text { Intellectual Disability }\end{array}$ & \\
\hline $\begin{array}{l}\text { External Factors } \\
\text { a. Parents role: } \\
\text { 1) parents are directly involved in } \\
\text { teaching and training } \\
\text { 2) understand the condition of the } \\
\text { child being affected } \\
\text { b. Parents attitude: } \\
\text { 1) Always protects because of pity } \\
\text { and worry (Subject } 1 \text { \& 4) } \\
\text { 2) Always pampered and helpful } \\
\text { even though the children is } \\
\text { capable of doing by her/himself } \\
\text { (Subject 4) } \\
\text { c. How to train self-care } \\
\text { d. Auxiliary tool (Subject 2) } \\
\text { e. Parental and teacher cooperation } \\
\text { (Subject 2) } \\
\text { f. Self-care programs in school } \\
\text { (Subject 2 and 4) }\end{array}$ & $\begin{array}{l}\text { The Five subjects } \\
\text { showed varying } \\
\text { ability in each } \\
\text { aspect of self-care } \\
\text { skills } \\
\text { a. Toileting } \\
\text { b. Feeding } \\
\text { c. Dressing } \\
\text { d. Personal } \\
\text { hygiene }\end{array}$ & $\begin{array}{l}\text { Internal Factors } \\
\text { a. Physical and motor } \\
\text { condition problem } \\
\text { (Subject 2) } \\
\text { b. No health behavior } \\
\text { and health } \\
\text { problems }\end{array}$ \\
\hline
\end{tabular}

\section{Figure 1. Self-care Skills of Children with Moderate Intellectual Disability and The Factors}

A very influential external factor is the attitude of the parents, it can inhibit the development of the subject's self- care, such as pampering, always helping the subject even though the subject is able to do the activity by him/herself. The figure of study result can be seen in the Appendix.

\section{DISCUSSION}

Self-care skill is the ability to care for themselves to maintain cleanliness and health which is a subcomponent of daily activities consisting of eating, dressing, toileting, and personal hygiene (Shenai and Wadia, 2014); Mash and Wolfe, (2005)). Although the five subjects showed a deficit in self-care ability 
compared to age matched children, the level of self-care ability achieved in each subject was different, implying that the amount of assistance needed was different (Mash and Wolfe, 2005).

Some children with moderate intellectual disabilities will continue to receive assistance throughout life but there are also some children who may need only a little help in their daily functions. These differences are influenced by several factors both internal and external. In the ability to feeding and personal hygiene, almost all subjects have been able to do independently without assistance, except for subject II who experience physical condition problem so she still needed help when eating, buttoning clothes, pulling zippers, pockets, and other activities that require coordination of both hands and motor skills.

The results are in accordance with Abreu, Barroso et al., (2015) that children's difficulties to develop themselves can be caused by internal factors, one of which is a physical problem. Internal factors are also related to disturbing behavior or aggressive behavior that can cause children's attention during training so that the teacher will first handle the disturbing or aggressive behavior before training new skills (Snell, 1983). The five subjects did not experience health and behavioral problems that hampered the provision of self-care training. The five subjects showed development in self-care ability also influenced by the role of parents who were directly involved in the daily teaching and training the subject where parental involvement proved to be influential in improving children's self-care abilities (Anand, 2012).

Some subjects in this study even already have the ability to develop themselves before entering school because parents have accustomed and trained them every day before the subject entered school. In addition, children can achieve the ability to dev- elop themselves which is also expected to be supported by stimulation provided by the mother (Stevenson, 1985), as found in parents of subject I, IV, and V, who practice toileting by arranging a toileting schedule.

The results of the study also showed the importance of training and support provided in training the self-care. Akhmetzyanova (2014) emphasized that the formation of selfcare abilities in children with intellectual disabilities does not occur spontaneously and training by parents, specialist or experts is needed for each skill to develop properly. An effective training of the skills of children with intellectual disabilities, especially the moderate level requires a special way as found in this study, both parents and teachers of the five subjects use the same way in training self-care that is patiently, slowly, repeatedly, and gradually. This is in accordance with Akhmetzyanova (2014) who showed that the skill will be faster and more effective achieved if given step by step.

The results also show that in addition to the role of parents and how to train self-care, other external factors such as collaboration between parents and school also influence the development of self-care of the five subjects. This is consistent with the results of previous studies showing that social support and resources sufficient or available can help children achieve the expected self-care abilities (Kearney-Nunnery in Katherine Mclaughlin Renpenning, 2003). Mash and Wolf (2005) also mentioned that although IQ scores of children with intellectual disabilities will be difficult to change, support of the environment can help children achieve their potential.

In addition, special methods or approaches that are adapted to the child's condition also affect the accomplishment of the self-care program. This is consistent with the results of previous studies showing that the self-care skills will be more easily achieved if 
the training given in a program allowing children to focus on the target within a certain time (Akhmetzyanova, 2014). Children with moderate intellectual disabilities with special training and adequate supervision can have self-care ability (Mash and Wolfe, 2005).

Other external factors are parental attitudes. It was found by us that parental attitudes toward difficulties and independence of the subject caused differences in selfcare shown by the subject, such as indulgence, always helping even though the child was able to do the activity, and too caring because of feelings of worry and pity.

This is consistent with the explanation of previous studies that the mother's parenting style is too pampering and parental attitudes toward children's independence (Giarelli et al. in Kirk and Beatty, 2010) and excessive parental protection (Hurlock, 1978) can negatively affect the achievement of independence in the ability to develop themselves.

\section{AUTHOR CONTRIBUTION}

Heni Gerda Pesau raised the initial study question, managed and ran data collection, ran qualitative analysis, drew figures of study result, wrote up manuscript. Endang Widyorini refined study questions, planned study design, interpreted results. Sri Sumijati suggested issues in the discussion, analyzed theory of its use, interpreted results.

\section{CONFLICT OF INTEREST}

The authors declare that the study was conducted in the absence of any commercial or financial relationships that could be construed as a potential conflict of interest.

FUNDING AND SPONSORSHIP This study sponsored by Universitas Atma Jaya, Makassar, South Sulawesi, Indonesia.

\section{ACKNOWLEDGEMENT}

The authors would like to thank to all respondents who are giving their time to be interviewed and supervisor for feedback on this study. The authors thank to Gilles van Luijtelaar from Radboud University, Nijmegen, Netherlands for thoughtful comments and suggestions on the paper.

\section{REFERENCE}

Abreu W, Barroso C, Segadães MdeF, Teixeira S (2015). Promotion of SelfCare in Clinical Practice: Implications for Clinical Supervision in Nursing. International Journal of Information and Education Technology, 5(1): 6-9. https://doi.org/10.7763/ijiet.2015.v5.466

Akhmetzyanova AI (2014). The development of self-care skills of children with severe mental retardation in the context of Lekoteka. World Applied Sciences Journal, 29(6): 724-727. https://doi.org/10.5829/idosi.wasj.2014.29.06.139 22

APA (2013). Diagnostic and Statistical Manual of Mental Disorder, fifth edition. Arlington, VA: American Psychiatric Association.

Anand BA (2012). Self-Care Abilities of Moderate Mentally Challenged Children and Parents Involvement in Their Care. Sinhgad e-Journal of Nursing.

Dowling M (2000). Young Children's Personal, Social, and Emotional Development. London: Sage Publication.

Ekaete R, Arikpo M, Chukwudi N, Obono ME, John J, Agbu M (2015). Mentally Retarded Children and Deficits in Daily Living Skills: Case Study of Calabar Municipality Local Government Area, Cross River State, Nigeria. IOSR Journal of Research \& Method in Education Ver. III, 5(2): 2320-7388. https://doi.org/10.9790/7388-05232126 
Gallahue DL, Ozmun JC (2006). Understanding Motor Development: Infant, Children, Adolescent, Adults (Sixth Edition). New York: McGraw-Hill Inc. Hurlock EB (1978). Perkembangan Anak Jilid 1 Edisi Keenam. Jakarta: Erlangga.

Renpenning KM (2003). Self-Care Theory in Nursing. http://qums.ac.ir/portal/file/?180442/Self-Care-Theory.pdf

Kirk S, Beatty S (2010). Evaluating self-care support for children and young people with long-term conditions, 1-225. Retrieved from http://www.netscc.ac.uk/hsdr/files/project/SDO_FR_o8-1715162_Vo1.pdf

Klein J (2006). Focus on the Right of Children with Disabilities to Live in the Community Focus on the Right of Children with Disabilities to Live in the Community. Retrieved from http://community-living.info/wp-content/uploads/2014/02/ECCL-AR-2006-FINAL.pdf

Mash EJ, Wolfe DA (2005). Abnormal Child Psychology - third edition. USA: Thomson Wadsworth.

Moleong LJ (2002). Qualitative Research Methodology. Bandung: PT Remaja Rosdakarya.

Papalia DE, Olds SW, Feldman RD (2009). Human Development (Perkembangan Manusia). $10^{\text {th }}$ edition. Jakarta: Salemba Humanika.

Ramawati D (2011). Faktor-faktor yang Berhubungan dengan Kemampuan Perawatan Diri Anak Tuna Grahita di Kabupaten Banyumas Jawa Tengah. (Skripsi, Program Magister Ilmu Keperawatan Universitas Indonesia).
Ramawati D, Allenidekania A, Besral B (2012). Kemampuan Perawatan Diri Anak Tuna Grahita Berdasarkan Faktor Eksternal dan Internal Anak. Jurnal Keperawatan Indonesia, 15(2), 89-96. https://doi.org/10.7454/jki.v15i2.32

Reis H, Sprecher S, Noller P (2013). Abuse and Violence in Relationships. Encyclopedia of Human Relationships. https://doi.org/10.4135/9781412958479.n2

Samsuri AF, Kesehatan FI, Surakarta UM (2013). Memandirikan Anak Retardasi Mental di SLBN. Retrieved from http://eprints.ums.ac.id/27146/12/NASKAH_PUBLIKASI.pdf

Shenai NG, Wadia DN (2014). Development of a self-care skills for children with developmental disorders: A pilot study. The Indian Journal of Occupational Therapy, 46: 16-21. http://medind.nic.in/iba/t14/i1/ibat14i1p16.pdf

Smith JA (2013). Dasar-dasar Psikologi Kualitatif - Pedoman Praktis Metode Penelitian (2 ${ }^{\text {nd }}$ Edition). Bandung: Nusa Media

Snell ME (1983). Systematic Instruction of the moderately and severely handicapped ( $2^{\text {nd }}$ Edition). Ohio: Bell \& Howell Company.

TATS eUpdate (2010). Developmentally Appropriate Practice - Adaptive/ Self-Help Skills. 1-6.

Tevenson JE (1985). Recent Research in Developmental Psychopathology. England: Pergamon Press Ltd.

World Health Organization (2004). ICD-10 guide for mental retardation. Mental Retardation, 82. Retrieved from http://www.who.int/whr/2001/chapter2/en /index4.html 